\title{
Autoetnograficzny dyskurs słowa i fotografii we współczesnej prozie polskiej
}

Współczesny dyskurs dotyczący języka werbalnego i wizualnego, ich wzajemnego oddziaływania oraz współwystępowania ewokuje negatywne treści, wskazując głównie na konflikt zachodzący między systemami, konflikt, w którym jednemu z nich pragnie się przypisać wyższość. Wtórne systemy modelujące, również język wizualny, funkcjonują w obrębie metajęzyka, dlatego uchwycić można podobieństwo w ich budowie - tym, czym dla języka werbalnego jest fonem i słowo, dla odmiany wizualnej są części składowe kompozycji - światło, barwa lub układ przedmiotów. Odnajdywanie różnic między literaturą a fotografią - przenosząc się na szerszy obszar - jest mniej płodne heurystycznie niż analiza koneksji, jakie między nimi zachodzą. Słusznie konstatuje François Soulages:

W istocie mowa i fotografia funkcjonują w sposób zupełnie odmienny. Pierwsza, w przeciwieństwie do drugiej, wykorzystuje kod. Istota pierwszej zasadza się na dwojakim połączeniu, zaś drugiej - na wzrokowym ekwiwalencie głosu. Pierwsza wiąże się z czasem zakutym w łańcuch (znaczeń), druga natomiast - z chwilą uwolnioną ze znakowości. Pierwsza byłaby znakiem, zaś druga - obrazem, [Soulages 2012: 295]

jednak podkreślić należy, że przede wszystkim współtworzą one wypowiedź artystyczną. W kontekście owego współwystępowania istotna jest relacja słowa/ podpisu pod fotografią i tekstu literackiego oraz samej fotografii, a w projektach fotograficznych napięcie pomiędzy obrazem i podpisem.

Interesującym obszarem układu tych dziedzin są utwory literackie oraz artystyczne o cechach autoetnograficznych, narracje przedstawiające wydarzenia, grupy społeczne czy zjawiska poprzez pryzmat doświadczenia, z założeniem subiektywnej optyki. Autoetnografia to według Carolyn Ellis:

Badanie, pisanie i metoda, które łączą to, co autobiograficzne i osobiste, z tym, co kulturowe i społeczne. Forma ta najczęściej opiera się na konkretnym działaniu, emocjach, ucieleśnieniu, 
samoświadomości i introspekcji [...] sięgając przy tym po różne konwencje literackie. [za: Holman Jones 2009: 177]

Egzemplifikacją metody badawczej jest powieść rodzinna, która prezentuje dzieje historyczne oddziałujące na jednostkę, widziane z jej punktu, czyli narracja mieszcząca się, jak określa ją Andrzej Zieniewicz, w nawiązaniu do społecznych ram pamięci Maurice'a Halbwachsa, w „ramach pamięci konkretnej osoby” [Zieniewicz 2011: 23]. Narracje rodzinne nie odtwarzają zatem całego tła historycznego, wydarzeń oraz aury, która im towarzyszyła, wydobywają z mnemonicznej przestrzeni jedynie to, co wpływa na tożsamość narratora. Należy jednak zaznaczyć, że ów narrator - podobnie jak historyk - rekonstruuje losy, inicjuje działanie, szuka informacji, innymi słowy wykonuje gesty dążące do odtworzenia życia przodków. Powieści rodzinne nie pretendują do całościowego ujęcia historii, starają się odtworzyć fragmenty minionego, zwracając uwagę na czynnik ludzki, który w opracowaniach naukowych często bywa niezauważony. Jak wnioskuje Natalia Lemann: „o ile dawna, tradycyjna historia była domeną zbiorowości, to pamięć jest domeną prywatności, ex definitione jest wieloraka, niejednorodna, magmowata" [Lemann 2008: 180].

Autoetnograficzna sfera powieści rodzinnych wiąże się także $\mathrm{z}$ umiejscawianiem się podmiotu tekstowego ( $\mathrm{w}$ tym wypadku tożsamego $\mathrm{z}$ podmiotem czynności twórczych) w i wobec narracji, konstytuowaniem osobowości, poznawaniem krewnych - perypetii oraz przynależnych im zachowań, na tle których można poznać siebie. Praca nad tekstem, trudy pamięci to przyglądanie się innym, stawanie się świadomą częścią całości, ale i możliwość wyodrębnienia swoich cech, uchwycenia wyjątkowości. Aspekt autoetnograficzny uwypuklają fotografie włączone w obręb dzieł literackich o takich cechach, ponieważ przynależą do przestrzeni pamięci, są jej nośnikami, współtworzą album rodzinny autora i to z niego pochodzą. Ponadto, jak pisze Roland Barthes: ,podobnej pewności, co zdjęcie, nie może dać żaden pisany tekst. To nieszczęście (a może rozkosz) języka, że nigdy nie może o sobie poświadczyć" [Barthes 2008: 152], co, nie wchodząc szczegółowo w rozbudowane teoretycznie rozważania nad referencyjnością tekstów o cechach autobiograficznych, paktach i autofikcjach, wydaje się istotne dla narracji tego typu.

W ogrodzie pamięci Joanny Olczak-Ronikier [Olczak-Ronikier 2002] to retrospekcyjna powieść czy, używając określenia Ewy Domańskiej ${ }^{1}$, mikrohistoria polsko-żydowskiej rodziny autorki, rozpoczynająca się od opisu życia prapradziadka - rabina Eleazara Horowitza. Pojęcie mikrohistorii ma silny związek z autoetnografią, ponieważ także zwraca się ku aspektowi personalnemu, wskazuje na narracje współtworzące wymiar „makro”. Powieści, która jest próbą odtworzenia

${ }^{1}$ Dokładną analizę powieści $W$ ogrodzie pamięci w kontekście teorii mikrohistorii przeprowadziła Natalia Lemann [Lemann 2008: 192-205]. 
losów bliskich oraz umiejscowienia ich na tle wydarzeń historycznych, towarzyszą zdjęcia i dokumenty - semiofory zebrane przez pisarkę. Niekiedy są one zaczątkiem opowieści, bo to jedyne ślady przeszłości, niteczki, które w żmudnym procesie poszukiwania informacji i stawiania pytań o ich pochodzenie, zostają włączone w tkankę rodzinnej pamięci. W ten sposób stają się fotografie przedmiotami, które pomagają wykonać pracę pamięci. Dzieje się tak na przykład ze zdjęciem przedstawiającym babkę autorki - Janinę Mortkiewiczową i jej koleżanki tuż po ukończeniu pensji dla dziewcząt. Olczak-Ronikier poszukuje tożsamości niektórych z nich, szuka przeszłości, bazując jedynie na jej śladach, strzępkach informacji. Uzyskiwanie wiedzy o osobach uchwyconych w kadrze oraz o samym zdjęciu jest także próbą weryfikacji opowieści babki, konfrontacją pamięci jednostkowej z tym, co udało się autorce ustalić. Fotografie są więc dokumentami, które przez wzgląd na swoją funkcję sygnują opowieść kwalifikatorem „prawda”, ale są także pamiątkami rodzinnymi otwierającymi sferę intymności. W kontekście fotografii-pamiątek ważny jest ich fizyczny wymiar - zniszczenia, stopień czytelności, a przede wszystkim droga, jaką przebyły w przeszłości, bowiem nośnikiem znaczeń jest nie tylko kadr, ale i jego losy. Jak pisze Andrzej Stasiuk w posłowiu do Pierścienia z papieru Zygmunta Haupta:

Przedmioty, rzeczywistość i w ogóle świat widzialny mają strukturę nieco geologiczną. Sensy i znaczenia narastają w nich stopniowo. Same w sobie są niewiele warte. Uszlachetnia je dopiero ciągłość percepcji, czyli wszyscy ludzie, którzy przed nami dotykali ich myślą, słowem albo po prostu ręką. [Haupt 1997: 262]

Zdjęcia włączone w obręb dzieła literackiego są nie tylko ilustracjami tekstu głównego, ale i artystycznym tematem - ekfrazą lub narracją rozpoczynającą się od fotografii. Kadry są zatem elementami, które zakorzeniają opowieść w przeszłości i wywołują wspomnienia. Tym samym organizują tkankę narracyjną, ponieważ wyzwalają reminiscencje dotyczące osób czy miejsc, a dalej domysły związane z fotograficzną przestrzenią, domysły dotyczące również tego, co znajduje się poza obszarem kadru i pamięci. Zaczyna wtedy pracować wyobraźnia, pojawiają się literackie wypełnienia mnemonicznej materii, które nie tylko ubarwiają fabułę, ale, jak zauważa Cezary Zalewski, sprawiają, że „od strony wizualnej, jak i przedmiotowej zostaje ona [fotografia - M. R.-K.] właśnie opowiedziana - a nie opisana" [Zalewski: 227]. Funkcję taką pełni zdjęcie z prologu Widnokręgu Wiesława Myśliwskiego czy fotografie z kolekcji Jacka Dehnela, które weszły w skład Fotoplastikonu. Podkreślić należy, że w tym ostatnim utworze zdjęcia mają status inny niż zdjęcia współtworzące powieści rodzinne, jednak znaczenie narracyjne (fotografia jako wyzwalacz opowieści) jest podobne.

Podpisy pod zdjęciami w $W$ ogrodzie pamięci zawierają informacje na temat miejsca i roku wykonania zdjęcia oraz nazwisko postaci, która została na nich 
utrwalona, czyli, wedle typologii Clive'a $\mathrm{Scotta}^{2}$, pełnią funkcję wyjaśniającą i syntetyzującą obraz. Nawet gdy autorka nie posiada wszystkich danych, podpis zachowuje ten status, ponieważ jest czysto informacyjny, nie manipuluje obrazem. Fotografie włączone w narrację Olczak-Ronikier nazwać można domowymi lub afektywnymi ${ }^{3}$, których cechą konstytutywną jest to, że w różny sposób postrzegane są przez osoby obce i te, które widzą w kadrze swoich bliskich; są zatem polisemiczne. Treści zawarte pod zdjęciami sprawiają, że portrety członków rodziny autorki stają się zrozumiałe również dla czytelnika, ponadto pomagają odnieść odpowiedni fragment narracji do obrazu, powiązać je, ponieważ, jak pisze Zalewski, dopiero fotografia ,włączona w rytm opowieści zaczyna wypełniać się znaczeniem" [Zalewski 2010: 238]. Podobnie wnioskuje Natalia Lemann:

Sam proces oglądania zaprezentowanych zbiorów to jednak za mało, byśmy weszli do ogrodu pamięci, wiedzą stają się one dopiero w momencie, gdy autorka nada im sens w obrębie rodzinnych wspomnień. [Lemann 2008: 191]

Wskazując na niefabularny charakter fotografii, wykonują badacze gesty podporządkowujące system wizualny systemowi językowemu, jednak, odchodząc od rozważań wartościujących i stawiając $\mathrm{w}$ centrum problem przenikania się tych sfer, twierdzić należy, że obie wpływają na kształt powieści Olczak-Ronikier, dopełniają się i uwypuklają aspekt autoetnograficzny.

Zarówno podpisy, fotografie, jak i fabuła $W$ ogrodzie pamięci tworzą aurę, którą porównać można do - odwołując się do metaforyki, jaką zastosował Przemysław Czapliński [2001], interpretując Widnokragg Myśliwskiego - przeglądania, pokazywania przez właściciela albumu rodzinnego i komentowania poszczególnych zdjęć. Fotografie w tak zorganizowanej, autobiograficznej przestrzeni pełnią funkcję zakotwiczającą w rzeczywistości, odsyłającą do komunikatu „to było”. Podpisy podtrzymują rolę kadrów, ponieważ nie narzucają punctum ${ }^{4}$, jedynie komunikują. Poprzez fotografie włączone w narrację również poznajemy losy jednostek, zbliżamy się do nich. Doświadczenie to najbardziej uderza w kontakcie ze zdjęciem, które, jak dowiadujemy się z tekstu, jest ostatnim wykonanym za życia kogoś bliskiego narratorowi. Fotografie są śladami przeszłości, mają utratę wpisaną w kadr, „w każdym zdjęciu jest władczy znak naszej przyszłej śmierci” pisze Barthes [Barthes 2008: 172]. Doznanie o takim charakterze opisuje Olczak-

${ }^{2}$ Clive Scott wymienia trzy funkcje podpisów pod fotografiami - podpis jako docelowe wyjaśnienie, podpis jako punkt wyjścia oraz podpis jako paralelny, ale oderwany od zawartości zdjęcia komentarz [za: Garncarek 2005: 234].

3 Jeden z trybów funkcjonowania fotografii, który wyróżnił F. Soulages obok fotografii definicyjnej lub informatywnej, fotografii reklamowej oraz artystycznej [Soulages 2012: 296].

${ }_{4}$ Punctum i studium to wyróżnione przez Rolanda Barthesa przestrzenie oddziaływania fotografii. Punctum to element kompozycji, który najmocniej przyciąga, skupia uwagę [Barthes 2008: 49-52]. 
-Ronikier w kontekście fotografii babci i jej siostry Róży. Zdjęcie znajduje się nie tylko wewnątrz narracji, ale i na okładce, jest zatem podwojone. Wyraża nostalgię wiązaną z obszarem wspomnień, z przeszłością, a także uchwyconym w kadrze momentem. Przywołując słowa autorki:

Jest w tym idyllicznym obrazku coś metafizycznego. Okruch życia, który zastygł na zawsze, jak w kropli żywicy. Rozpędzony czas na chwilę stanął w miejscu [Olczak-Ronikier 2005: 186].

Zdjęcie dokumentuje ostatnie spotkanie sióstr, spotkanie, w którym uczestniczyła również mała Joanna, dlatego jej postać także została utrwalona przez stop-klatkę. W ten sposób sportretowano chwilę, która w niezwykły sposób zespala wątki opisywane przez autorkę. Podobne doświadczenia (oraz zdjęcia) pojawiają się w postpamięciowej powieści Rodzinna historia lęku Agaty Tuszyńskiej ${ }^{5}$, której forma jest zbliżona do omawianej powieści, o uczuciu tym wspomina też Barthes, opisując zdjęcia matki, a w tekstach teoretycznych m.in. cytowani Soulages i Zalewski.

Mercedes-Benz. Z listów do Hrabala Pawła Huellego [2003] to utwór, w którym słowo i fotografia wchodzą ze sobą w dyskurs, podkreślając autoetnograficzny charakter narracji. Zauważyć należy, że udostępnienie prywatnych zdjęć autora, podobnie jak w powieści $W$ ogrodzie pamięci, akcentuje jeszcze mocniej jednostkową perspektywę, osobiste doświadczenie zakorzenione w przeżyciach zbiorowych. W tym przypadku historia, z którą zmaga się rodzina, oraz narrator, jak i fotografie, podporządkowane są chwytowi motoryzacyjnemu, zaczerpniętemu z Wieczornej lekcji jazdy Bohumila Hrabala. Ograniczenie to wpływa na relacje między tekstem, fotografiami i podpisami, sprawia również, że fabuła jest alinearna, nie dąży do odtworzenia perypetii rodzinnych, lecz ewokuje wspomniane treści. $\mathrm{W}$ odniesieniu do struktury autobiograficznej powieści zasygnalizować należy również nadrzędną rolę gawędy i opowiadacza, która wpływa na refleksję dotyczącą jej referencyjności. Dominanta motoryzacyjna oraz żywioł mowy sprawiają, że odtworzone zostają jedynie fragmenty rodzinnej przeszłości, odpowiednio przefiltrowane przez główny motyw. Choć w niewielkim stopniu pozwala on na ukazanie losów poszczególnych bohaterów, zmiany historyczne najmocniej zapisane są w kontekście przestrzennym - Gdańsk wykreowany jest przez Huellego jako palimpsest. Wędrówkom po mieście oraz nauce jazdy towarzyszą refleksje związane z przekształceniami funkcji poszczególnych budynków i tożsamością ulic zapisaną w ich nazwach. Poprzez tak zorganizowaną narrację oraz zakorzenione w niej fotografie pokazuje autor kreacyjną moc strzępków, elementów mnezyjnych, z których może opowiadacz zbudować barwną narrację, odwołując się, jak zostało napisane w rozważaniach o powieści Olczak-Ronikier,

${ }^{5} \mathrm{Na}$ podobieństwa narracji Olczak-Ronikier i Agaty Tuszyńskiej zwraca również uwagę Cezary Zalewski, zestawiając je w jednym rozdziale swojej książki [Zalewski 2010: 234-238]. 
do wyobraźni. Zdjęcia domowe lub afektywne są ukonstytuowane w utworze przez fabułę, dominuje w nich ilustracyjność względem niej. Symbolicznie rzecz ujmując, fotografie w Mercedesie-Benzie... to zamknięte w kadrze narracje, jej echa. Gdy opowiada Huelle o ślubie dziadków, pojawia się zdjęcie z wydarzenia, podobnie z zawodami automobilowymi, a dookreślając - pogonią za sztuczną kitą przypiętą do balona. Autor tworzy także, by posłużyć się kategorią Marka Zaleskiego, „,iterackie kadry pamięci” [Zaleski 2004], które są transpozycją obrazu fotograficznego. Narracyjna transpozycja w utworze Huellego wzmocniona zostaje kopią fotografii, do której się odnosi, oraz podpisem będącym cytatem z tekstu głównego. Trudno jednoznacznie zdefiniować charakter takich podpisów, ponieważ są one multiplikacją obrazu oraz „literackiego kadru pamięci”, co wpływa również na postrzeganie relacji słowa i fotografii. Zdjęcia dołączone do tekstu nie mają charakteru współtworzącego, pełnią raczej funkcję estetyczną, pokazują wizerunki osób, do których odnosi się narracja, ale nie wpływają na jej interpretację. Ponadto, zakorzeniają opowieść w rzeczywistości, wiążą ją z konkretnymi postaciami, czyli wpływają mocniej niż język na autoetnograficzny wymiar utworu. Być może przyczyną tak kształtujących się koneksji jest fakt, że Huelle nie planował włączyć fotografii w obręb Mercedesa-Benza..., dokonał narracyjnej prezentacji - jaką znamy chociażby z przywoływanego wcześniej Widnokręgu czy Fotografii Janusza Andermana - a zdjęcia zaproponował wydawca książki.

Niektóre $\mathrm{z}$ fotografii uzupełnione są podpisem informacyjnym, jednak nie można potraktować treści tej, jak we wcześniejszym utworze, jako wyjaśniającej i syntetyzującej obraz, ponieważ brak w niej podstawowych danych. Pierwszy z podpisów o tym aspekcie: „Ślub Marii i Karola we Lwowie” [Huelle 2003: 27] jest najbardziej zbliżony do typu opisanego przez Scotta, ale nie odsłania przed czytelnikiem dodatkowych treści, wszystko zostało opowiedziane zarówno w toku narracji, jak i przez samą fotografię oraz miejsce jej wkomponowania w tekst. Kolejne - „Dziadek Karol pierwszy z prawej” [Huelle 2003: 56] oraz „Wnętrze pociągu pancernego, dziadek Karol pierwszy z prawej” [Huelle 2003: 80] odsyłają do konkretnej osoby, czyli wyjaśniają, ale nie określają tożsamości innych ludzi uchwyconych przez spektrum. Co ciekawe, w podpisach tych nie znajdziemy nazwisk bohaterów, sygnatura jest tożsama $\mathrm{z}$ tą, jaka pojawia się w narracji Huellego - dziadek, babcia/Karol, Maria, tym samym podpis sprawia wrażenie przygotowanego przez autora, wypowiedzianego z jego perspektywy, co również poszerza przestrzeń prywatności udostępnioną czytelnikowi. Wrażenie intymności wstrzymuje podpis „Ojciec autora przed citroenem” [Heulle 2003: 87], wskazując na zewnętrzną instancję wkraczającą w obszar dzieła literackiego, instancję, która przerywa wrażenie obcowania z właścicielem albumu oraz, po raz kolejny, uwypukla zgrzyty, pęknięcia w relacji obraz - słowo.

Rozważając koneksje fotografii i narracji w Mercedesie-Benzie..., dopowiedzieć należy, że zdjęcia dołączone do utworu kontynuują wątek dziadka autora, 
który przez całe swoje życie amatorsko fotografował. Wybuch II wojny światowej spowodował, że bohater opowieści spojrzał inaczej na rodzinną kolekcję, zaczął ją opisywać, porządkować i uzupełniać brakującymi danymi. Zachowanie to połączyć można z teorią pamięci-archiwum i pamięci-obowiązku Pierre’a Nory:

[...] Czujemy się zobowiązani do wytrwałego kolekcjonowania pozostałości, świadectw, dokumentów, obrazów, pogłosek, jakichkolwiek widzialnych znaków tego, co było, tak jakby to pęczniejące dossier miało być wykorzystane jako dowód przed nieznanym jeszcze trybunałem historii. [Nora 2009: 7]

Cytując słowa Huellego, które przez metaforę czasu współbrzmią również z przywoływaną refleksją Olczak-Ronikier: „Okruch życia, który zastygł na zawsze, jak w kropli żywicy” [Olczak-Ronikier 2005: 186].

Marysiu, szczęśliwsi to my już nigdy nie będziemy, trzeba te wszystkie chwile zatrzymać jak owada w bursztynie, przechować może nawet dla naszych wnuków. [Huelle 2003: 78]

Artystyczny projekt Mariusza Hermanowicza Stryj Piotr ${ }^{6}$, choć zakorzeniony jest w medium fotograficznym, otwiera obszar dialogu między obrazem a słowem i jest opowieścią o przeszłości oraz o rodzinie. Fotografik w artystycznym geście, podobnym temu, jaki wykonuje Joanna Olczak-Ronikier, stara się zrekonstruować losy stryja - Piotra Hermanowicza - zaginionego we wrześniu 1939 r., po wejściu wojsk radzieckich do Wilna. Efektem owych poszukiwań, wyłuskiwania z przestrzeni historycznej jednostkowego doświadczenia, odbudowywania pokruszonej przez przeszłość pamięci jest autoetnograficzna praca składająca się z 21 zdjęć, opatrzonych nie tylko podpisami, ale i wspomnieniami innych członków rodziny oraz refleksjami samego autora, czyli narracją. Część kadrów przedstawia sylwetkę stryja, część narzędzia wykonane przez niego podczas praktyki rzeźbiarskiej - przedmioty, które obrosły znaczeniami, stały się nośnikami pamięci, również przez wzgląd na pokrewieństwo zainteresowań autora projektu oraz jego przodka. Tworzy zatem autor kolekcję, zbiera pamiątki związane z działalnością i życiem stryja, włącza je w tkankę rodzinnej pamięci. Choć autoetnograficzny charakter pracy wiąże się pośrednio z odczytywaniem historii stryja, to w sposób bezpośredni dotyczy samego Hermanowicza, który, mimo że urodził się jedenaście lat po jego zaginięciu, odczuwał potrzebę scalenia pamięci. Dzięki swoim działaniom zdobywa fotografik wiedzę, a przede wszystkim konstytuuje własną tożsamość, jak pisze pod jednym ze zdjęć:

Stryju Piotrze, nie wiem czy byłbyś zadowolony z rezultatów mojego „dochodzenia”, pewnie wolałbyś, bym podkreślał Twoje zasługi jako rzeźbiarza. Ale mnie właśnie Ty interesowałeś, właśnie Ciebie chciałem spotkać, z Tobą porozmawiać. Tyle już lat myślę o Tobie, wydaje mi się, że Cię już tak dobrze znam, czasami czuję, że wejdziesz zaraz, że usiądziesz do stołu, zjemy dobry obiad ze słoikiem borówek tylko dla Ciebie.

${ }^{6}$ M. Hermanowicz, Stryj Piotr, Galeria GGF, Gdańsk 1993. 
Projekt autora nazwać można za Marianną Michałowską foto-tekstem, czyli pracą o większej refleksyjności, komentującą przedmiot odniesienia, a przede wszystkim taką, która tworzy narrację [Michałowska 2012]. Otrzymana opowieść jest w takim przypadku wynikiem współbrzmienia kodu językowego i wizualnego, bowiem, jak pisze Janina Struk: „Obiegowa opinia na temat fotografii - każde zdjęcie opowiada jakass historię lub obraz wart jest tysiaca słów - ma znaczenie tylko pod warunkiem, że kontekst lub historia zostały już ustalone" [Struk 2007: 279]. Opinia badaczki dotyczyła fotografii Zagłady, ale i tu wybrzmiewa odpowiednio, ponieważ same zdjęcia rodzinne czy przedmioty pracy stryja nie odsłoniły przed autorem znaczeń, dopóki nie poznał ich historii. Dopóki przedmioty nie zostały włączone w narrację, były jedynie śladami przeszłości. Dlatego rozpoczął Hermanowicz, jak określa w przytoczonym fragmencie, „dochodzenie” - poszukiwanie informacji o stryju, retrospekcji zapisanych w pamięci rodziny czy w dokumentach i wycinkach gazet, tym samym wzbogacił obrazy słowem.

Materialnym wynikiem pracy autora jest projekt Stryj Piotr, którego forma odwzorowuje wszystkie etapy jego przygotowywania, sumuje zebrane materiały, przeprowadzone rozmowy. Warto zaznaczyć, że autorskie refleksje zapisane są w większości odręcznie, co zakorzenia pracę jeszcze mocniej w przestrzeni autoetnograficznej. Relacja zachodząca pomiędzy podpisami i fotografiami w sposób symboliczny wyraża stosunek kodu wizualnego i werbalnego, stosunek który wybrzmiewa w całym projekcie, by przywołać ich część: „Dłuto, które należało do stryja Piotra. Złamałem je, urządzając nasze mieszkanie w Warszawie", „Stryj Piotr ze słuchaczami Szkoły Rzemiosł Artystycznych. Wydaje mi się, że to zdjęcie pochodzi z lat 1924-1926. Jakieś dziecko zapewne porysowało zdjęcie ołówkiem” czy „Ale czemu stryj Piotr tak zasłonił siedzącą obok niego dziewczynę swoim ramieniem? Czy tylko dlatego że było ciasno? Wydaje mi się, że nie. Wspomnienia rzucają ciekawe światło na stosunek stryja do kobiet”. Podpisy o takim charakterze nazywa Scott paralelnymi, ale oderwanymi od zdjęcia komentarzami [za: Garncarek 2005: 234], wskazując na znaczenie, które nie zawiera się ani w fotografii, ani w podpisie, lecz w miejscu ich przecięcia.

François Soulages jako jeden ze sposobów współdziałania słowa i fotografii wymienia projekt, który jest wynikiem pracy dwóch artystów [Soulages 2012: 311-314]. Egzemplifikacją spostrzeżenia teoretyka jest Dziennik pisany później [Stasiuk 2010] Andrzeja Stasiuka z fotografiami Dariusza Pawelca. Dopowiedzieć jednak należy, że zdjęcia powstały wcześniej - Stasiuk dołączył fotograficzny reportaż do swojego tekstu, nie jest to zatem wspólny koncept, lecz dwie artystyczne całości, które stworzyły przestrzeń utworu. Dlatego też Dziennik... funkcjonuje pod nazwiskiem pisarza, ale mimo wszystko na okładce wymienieni są obaj twórcy, a wewnątrz znajdują się dwa biogramy.

W Dzienniku... dyskurs autoetnograficzny nie dotyczy, jak we wcześniejszych przykładach, osobistej narracji przedstawionej na tle narracji historycznej, ale przestrzeni, aury miejsca - w tym przypadku Bałkanów ukazanych z punktu widzenia jednostki. Tym samym teren i tożsamość mieszkańców zaprezentowa- 
ne zostają nie poprzez etnograficzne badania, ale doświadczenie, wiedzę, którą nabył o nich konkretny człowiek. To gatunkowe przesunięcie z powieści rodzinnej w kierunku reportażu potrzebne jest, by w pełni zaprezentować dyskurs słowa/podpisu i obrazu we współczesnej prozie polskiej, ponieważ utwór Stasiuka w interesujący sposób podchodzi do tej materii, zrównując ze sobą kod wizualny i werbalny. Ponadto autoetnografia jako metoda badawcza służy przede wszystkim badaniom etnograficznym, zastępując podejście socjologiczne, czyli badania jakościowe i ilościowe. Literatura jest w tym kontekście obszarem wdzierającym się w świat nauki, świadczącym jej przysługi.

Korespondencja obrazu i słowa w Dzienniku... dotyczy kilku płaszczyzn. Jedną z nich jest poruszona już kwestia współtwórstwa, kolejne to występowanie w każdej z tych dyscyplin analogicznych gatunków oraz koneksje, jakie zachodzą między zdjęciami, podpisami a tekstem Stasiuka. Fotografia i literatura to dziedziny artystyczne, które, choć używają różnych kanałów przekazu, wypowiadają podobne treści, stąd funkcjonowanie w ich obrębie pokrewnych gatunków - na przykład wymienianego już reportażu czy autobiografii, które spełniają te same założenia teoretyczne. Dziennik... trudno jednoznacznie zaklasyfikować, podobnie jak duża część twórczości Stasiuka określany jest mianem literatury podróżniczej, a nawet quasi-podróżniczej, ale charakter utworu pisarza tożsamy jest $\mathrm{z}$ konceptem fotograficznym Pawelca. Oba zakorzenione są w przestrzeni Bałkanów, prezentują atmosferę, a przede wszystkim mentalność i paradygmat ludzi zamieszkujących te tereny, dlatego obrazową formą reprezentacji w utworze są portrety, a po stronie werbalnej, nawiązujące do ich charakteru, literackie dagerotypy - jak można określić profil narracji Stasiuka, odwołując się do wiedzy o pierwotnej formie zdjęć oraz wykonując gest w kierunku uznanego już artykułu Antoniny Lubaszewskiej [1999] $W$ daguerotyp raczej pióro zamieniam. Pisarz odtwarza bowiem nawet najmniejsze szczegóły ujrzanych przestrzeni, nie tylko zapachy czy kolory, ale wszystko, co związane z degradacją świata - śmieci, brud, rozpadającą się rzeczywistość, tym samym narracja zbliża się do medium fotograficznego, które potrafi zarejestrować detale. Narracyjne współbrzmienie słowa i obrazu podkreślone zostało typograficznym układem, bowiem fotografie pojawiają się wewnątrz narracji (strony 49-80), nie mają podpisów, nie odnosi się do nich również w swoim tekście Stasiuk. Zabieg podkreśla narracyjne możliwości fotografii, czyli foto-tekstualność i znosi wartościujący dyskurs. Tym samym w centrum stawia problem współwystępowania języka werbalnego i wizualnego oraz ich wzajemnego oddziaływania, które nie tylko przyczynia się do powstawania interesujących dzieł literackich, fotograficznych czy chociażby performatywnych, ale podkreśla okulocentryczny charakter współczesnej kultury.

François Soulages w Estetyce fotografii. Stracie i zysku postuluje spojrzenie na język werbalny i wizualny jako kody współwystępujące w przestrzeni literackiej, umieszczając rozważania na ten temat w rozdziale zatytułowanym Wspóttworzenie [Soulages 2012: 293-319]. Tytuł ten ma nie tylko symboliczne znaczenie, przenosi również ciężar dyskursu z rozważań nad przewagą fotografii 
lub słowa na refleksję nad relacjami, które między nimi zachodzą oraz funkcjami, jakie może pełnić zdjęcie/obraz w tekście literackim. Współczesna proza polska pokazuje, że koneksje te są rozległe - poczynając od zwykłej ilustracyjności, ważnych funkcji narracyjnych fotografii - nośnika pamięci, toposu rozpoczynającego fabułę (zakorzeniającego ją w przeszłości), przedmiotów, kolekcji, pamiątek uwypuklających autoetnograficzny charakter, kończąc na artystycznych projektach, w których słowo i zdjęcie są tak samo wartościowane, przekazują podobne emocje. W utworach tych język ma moc wskrzeszania obrazów, a fotografia staje się narracją, która nie musi być wspierana żadnym słowem.

\section{Bibliografia}

Barthes R. [2008], Światto obrazu. Uwagi o fotografii, przeł. J. Trznadel, Wydawnictwo Aletheia, Warszawa.

Czapliński P. [2001], Epopeja spetnionej nostalgii, [w:] tenże, Wzniosłe tęsknoty: nostalgie w prozie lat dziewięćdziesiatych, Kraków, s. 55-64.

Garncarek M. [2005], Instrukcja obstugi obrazu, [w:] T. Ferenc, K. Makowski (red.), Przestrzenie fotografii. Antologia tekstów, Łódź, s. 227-250.

Haupt Z. [1997], Pierścień z papieru, Wydawnictwo Czarne, Wołowiec.

Holman Jones S. [2009], Autoetnografia. Polityka tego, co osobiste, przeł. M. Brzozowska-Brywczyńska, [w:] N. K. Denzin, Y. S. Lincoln (red.), Metody badań jakościowych, t. 2, Wydawnictwo Naukowe PWN, Warszawa, s. 175-218.

Huelle P. [2003], Mercedes-Benz. Z listów do Hrabala, Wydawnictwo Znak, Kraków.

Lemann N. [2008], „Przywoływatam cienie, odpowiedzieli mi żywi”: W ogrodzie pamięci Joanny Olczak Ronikier jako dyskurs podwójny-pamięci i mikrohistorii, [w:] taż, Epicka historiografia we wspótczesnej prozie polskiej, Wydawnictwo Uniwersytetu Łódzkiego, Łódź.

Lubaszewska A. [1999], W daguerotyp raczej pióro zamieniam, „Teksty Drugie”, nr 4, s. 165-183.

Michałowska M. [2012], Foto-Teksty. Zwiazki fotografii z narracją, Wydawnictwo Naukowe UAM, Poznań.

Nora P. [2011], Między pamięcia a historia: Les lieux de memoire, przeł. M. Borowski, M. Sugiera, „Didaskalia” nr 10, s. 20-27.

Olczak-Ronikier J. [2002], W ogrodzie pamięci, Wydawnictwo Znak, Kraków.

Soulages F. [2012], Estetyka Fotografii. Strata i Zysk, przeł. B. Mytych-Forajter, W. Forajter, Towarzystwo Autorów i Wydawców Prac Naukowych Universitas, Kraków.

Stasiuk A. [2010], Dziennik pisany później, Wydawnictwo Czarne, Wołowiec.

Struk J. [2007], Holocaust w fotografiach. Interpretacje dowodów, przeł. M. Antosiewicz, Wydawnictwo Prószyński i S-ka, Poznań.

Zaleski M. [1996], Formy pamięci. O przedstawianiu przeszłości w polskiej literaturze współczesnej, Wydawnictwo słowo/obraz terytoria, Warszawa.

Zalewski C. [2010], Narracyjna funkcjonalizacja fotografii w autobiografiach rodzinnych, [w:] tenże, Pragnienie, Poznanie, Przemijanie. Fotograficzne reprezentacje w literaturze polskiej, Towarzystwo Autorów i Wydawców Prac Naukowych Universitas, Kraków, s. 225-240.

Zieniewicz A. [2011], Pakty i fikcje. Autobiografizm po końcu wielkich narracji (szkice), Dom Wydawniczy ELIPSA, Warszawa. 